anales de psicología / annals of psychology

2019, vol. 35, nº 2 (may), 300-313

http://dx.doi.org/10.6018/analesps.35.2.333101
(C) Copyright 2019: Editum. Servicio de Publicaciones de la Universidad de Murcia. Murcia (Spain) ISSN print edition: 0212-9728. ISSN on line edition (http://revistas.um.es/analesps): 1695-2294.

On line edition License Creative Commons 4.0: BY-NC-ND

\title{
Dating violence (DV): a systematic meta-analysis review
}

\author{
Marcela Gracia-Leiva ${ }^{1}$, Alicia Puente-Martínez ${ }^{1 *}$, Silvia Ubillos-Landa ${ }^{2}$, and Darío Páez-Rovira ${ }^{1}$
}

1 Department of Social Psychology and Methodology of Behavioural Sciences. University of the Basque Country (Spain) 2 Department of Social Psychology. Faculty of Health Sciences. University of Burgos (Spain)

\begin{abstract}
Título: La violencia en el noviazgo (VN): una revisión de meta-análisis. Resumen: Esta revisión bibliográfica sintetiza los resultados de estudios meta analíticos sobre factores de riesgo y protección asociados a la Violencia en el Noviazgo (VN). Se incluyeron 15 meta-análisis publicados entre 1997-2018, $N=1784018$, y se clasificaron según el modelo socioecológico. Se calcularon las $Z r$ media para cada variable y nivel, incluyendo las diferencias en los tamaños del efecto medio entre victimización y perpetración de $\mathrm{VN}$ y, posteriormente, se transformaron a $r$. Se encontró que los factores de riesgo con mayor peso asociados a $\mathrm{VN}$, según nivel, fueron: (1) individual: consumo de tabaco y embarazo precoz (victimización) y sexo (perpetración/victimización); (2) microsistema: acoso sexual de pares (victimización), $\mathrm{VN}$ de los pares, tener amigos con conductas problemáticas y sufrir violencia en familia de origen (perpetración/victimización); (3) exosistema: edad (victimización) y barrio (perpetración/victimización) y (4) macrosistema: minoría cultural y desventaja económica (perpetración/victimización). Factores protectores de VN fueron: apoyo social de pares y parentalidad positiva, pero con menos peso. El tamaño del efecto fue mayor para las variables de nivel exo, frente a las macro, individual y micro respectivamente. Hay diferencias entre los tamaños del efecto totales, siendo en el exosistema mayor en victimización que en perpetración. Delimitar los factores de riesgo y protección con mayor efecto sobre $\mathrm{VN}$ resulta fundamental para prevenir este problema.
\end{abstract}

Palabras clave: Violencia en el Noviazgo; Revisión de meta análisis; Modelo socio-ecológico; Factores de riesgo y protectores.

\section{Introduction}

Dating violence (DV) is a widespread problem during adolescence (Wincentak, Conolly \& Card, 2016) which involves intentional sexual, physical or psychological acts or abuse by one member of a dating couple towards the other (Jennings et al., 2017; Public Health Agency of Canada, 2012). DV occurs within the context of an intimate romantic and/or sexual relationship between young people, with differing degrees of formality (Vagi et al., 2013), who do not live together and have neither children nor any binding legal or economic ties (Shorey, Cornelius \& Bell, 2008; Viejo, 2014).

According to a systematic review carried out by Jennings et al. (2017), the prevalence rate of DV is between $6 \%$ and $21 \%$ among men, and between $9 \%$ and $37 \%$ among women. However, the study did not analyze differences between the two sexes as regards perpetration and victimization. Other international studies have found similar prevalence rates for physical DV, reporting that between $10 \%$ and $25 \%$ of both men and women have suffered this kind of violence (Viejo,

* Correspondence address [Dirección para correspondencia]: Alicia Puente-Martínez. Department of Social Psychology and Methodology of Behavioural Sciences, University of the Basque Country UPV/EHU. Avenida Tolosa 70, CP 20018, San Sebastián (Spain).

E-mail: alicia.puente@ehu.eus

(Article received: 31-05-2018; revised: 28-09-2018; accepted: 15-10-2018)
Abstract: This study summarizes the results of meta-analyses about risk and protective factors related to dating violence (DV). Fifteen studies were included from 1997 to 2018, $N=1784018$. The results were classified according to ecological theory. The $\mathrm{Z} r^{2}$ s were calculated for each factor and level of analysis, including the differences between victimization and perpetration effect sizes. Then, the Z $r^{\prime}$ s were transformed to $r$ values. In accordance with the different levels of analysis, results showed that the effect sizes were greater for: (1) individual level: cigarette smoking, adolescent pregnancy (victimization) and sex (perpetration/victimization); (2) microsystem: peer sexual harassment, (victimization), peer DV, deviant peers and family violence (perpetration/ victimization); (3) exosystem: age (victimization) and violent neighborhoods (perpetration/ victimization), and (4) macrosystem: cultural minority and disadvantaged neighborhoods (perpetration / victimization). DV protective factors which had the lowest effect sizes were: parental and peer support; and highest effect sizes were found in the exo and macro levels, and then in the individual and micro levels. Furthermore, statistically significant differences between total effect sizes were found, with values being higher in the exosystem for victimization than for perpetration. Delimiting the most important risk and protective factors for DV has important implications for prevention and intervention.

Keywords: Dating violence; Meta- review; Social-ecological model; Risk and protective factors.

Monks, Sánchez \& Ortega-Ruiz, 2016; Wincentak et al., 2016). Studies measuring both sexual and physical violence have found that 1 out of every 5 adolescents (18\%-20\%) claim to have been subjected to DV by their partner (Silverman, Raj, Mucci \& Hathaway, 2001). International studies measuring only sexual violence report prevalence rates among women of between $9 \%$ and 13\% (Kliem, Baier \& Bergmann, 2018; Lau, Nguyen \& Markham, 2018). In general, psychological DV rates are higher than those for physical violence, although studies report varying results, with rates ranging between $30 \%$ and $92 \%$ (Fernández-González, O’Leary \& Muñoz-Rivas, 2014; Orpinas, Hsieh, Song, Holland \& Nahapetyan, 2013; Ybarra, Espelage, Langhinrichsen-Rohling \& Korchmaros, 2016).

In Spain, the prevalence of DV among the youth population has risen $(n=5634)$ (Ministry of Health, Social Services and Equality, 2015). According to the Macro-survey of Violence Against Women carried out in 2015, 11.7\% of female adolescents and young women claim to have been victims of physical or sexual violence (Hernández Oliver \& Doménec del Río, 2017). Some authors have linked DV to violence suffered by women during adulthood. For example, studies carried out among the adult clinical population have found that intimate partner violence (IPV), perpetrated by men against women, had been present since courtship (Amor, Echeburúa, De Corral, Sarasua \& Zubizarreta, 2001; Black et al., 2011). 
As regards the consequences of DV, female adolescent victims have been found to have lower self-esteem and a higher level of emotional dependency than non-victims (Moral, García, Cuetos \& Sirvent, 2017). Other studies have found that DV is linked to adverse long-term health outcomes among women (Howard, Debnam \& Wang, 2013). DV is associated with increased feelings of guilt, rage, pain and anxiety (Cornelius \& Resseguie, 2007), as well as with other negative effects such as reduced psychosocial wellbeing and poor academic performance (Zaha, Helm, Baker \& Hayes, 2013). Moreover, recent studies have also found that DV is linked to higher rates of suicidal ideation and depression (Singh et al., 2014; Silverman et al., 2001).

Many studies have attempted to identify the risk factors associated with DV victimization and perpetration and to develop prevention methods aimed at minimizing its consequences. Some of the individual factors that have been identified include low frustration tolerance, externalizing problems and sexism, all of which have been linked specifically to the perpetration of DV (Pazos, Oliva \& Gómez, 2014). Alcohol misuse during adolescence and early sex initiation (age 12 to 14 ) predict DV perpetration among men (Niolon et al., 2015). As regards the interpersonal factors associated with DV, aggression in peer relations has been found to positively predict DV perpetration and victimization (Ellis, Chung-Hall \& Dumas, 2013). Moreover, sexual abuse during childhood has been linked to both physical dating violence victimization and psychological violence perpetration (Cyr, McDuff \& Wright, 2006). One of the most controversial sociodemographic factors associated with DV is sex differences in both perpetration and victimization rates (Muñoz-Rivas, González-Lozano, Fernández-González, Fernández Ramos \& García Sánchez, 2015; Rubio-Garay, Carrasco, Amor \& López-González, 2015). Most studies identify women as being more at risk of suffering severe violence at the hands of their intimate partners (Hirigoyen, 2005; Shorey et al., 2008), and female adolescents as being more at risk of suffering violence in general than their male counterparts (Reidy et al., 2016; Singh et al., 2014). Moreover, it has been found that, among women, when individual risk factors (being pregnant or having children, suffering from mental illness and being in trouble with the law) combine with contextual risk factors (living on the streets or being in care), the DV victimization $(34 \%)$ and perpetration $(45 \%)$ rates are higher than for the general population (Joly \& Conolly, 2016). Nevertheless, other studies on DV have failed to find any significant sex differences in relation to victimization (Sebastián, Verdugo \& Ortiz, 2014), and when higher levels of violence have been recorded among women, most studies conclude that the statistical magnitude of this difference is small. One possible explanation for this is that these studies do not take into account women's tendency to underestimate violence (Fernández-Fuertes \& Fuertes, 2010; Pazos et al., 2014). According to Ferrer Pérez and Bosch Fiol (2005) and Bosch Fiol and Ferrer Pérez (2012, 2013), the bidirectional nature of DV suggested by some authors (Reidy et al., 2016; Viejo et al.,
2016) can be linked to biases in the instruments, which assume that intimate partner abuse occurs in equal and symmetrical conditions, disassociating it from the violence perpetrated in the social environment in which it takes place and ignoring the macro level of analysis, including gender inequality.

In over three decades of research into DV, the principal systematic reviews have identified between 20 and 50 variables associated with aggression and victimization (Jennings et al., 2017; Lewis \& Fremouw 2001; Vagi et al., 2013; Vezina \& Hebert, 2007), thus confirming the complex, multi-causal nature of the problem. Recent meta-analyses have summed up the most commonly-studied risk factors associated with DV (Hérbert et al., 2017; Park \& Kim, 2018). Nevertheless, the results have never yet been integrated into a global, structured analysis model, as have those pertaining to intimate partner violence in adult couples (Puente-Martínez, UbillosLanda, Echeburúa y Páez-Rovira, 2016).

From a theoretical perspective, Dutton (1995) proposes the social-ecological model as a means of understanding intimate partner violence within a system with different levels of analysis: ontogenetic, microsystem, exosystem and macrosystem. The ontogenetic level refers to each person's individual characteristics, attitudes, beliefs and behaviors. The microsystem level refers to the immediate environment in which the relationship takes place, i.e. the aspects or groups that influence the transmission of violence. The exosystem is made up of the formal and informal social structures that connect an individual to their family and broader context. And finally, the social or structural macrosystem encompasses the cultural values present in the region in which the couple lives, along with the political and economic landscape. Dutton (1995) explains that all of these factors combine to determine the likelihood of abuse taking place, although he also points out that no single factor is enough, or even necessary, to guarantee the occurrence of violence. Nevertheless, this author only applied the model to the analysis of the variables associated with aggression and violence among adult couples. Subsequently, Heise (1998) used the ecological model to conduct an analysis encompassing the gender perspective, taking into account also other risk factors linked to aggression and violence against women. Similarly, and again using the ecological model as their basis, other studies broadened the search for risk factors to include the field of violence victimization between intimate partners. The study by Stith, Smith, Penn, Ward \& Tritt (2004) analyzed the factors associated with violence victimization among adult intimate partners, and that conducted by Vezina and Hebert (2007) explored those linked to DV victimization among young women. No new reviews were then carried out until 2016, when the most recent results regarding intimate partner violence were integrated systematically into the ecological model by Puente-Martínez et al. (2016). However, although the social-ecological model has thus been confirmed as the most suitable model for analyzing intimate partner violence, there are as yet no applied models to de- 
termine the relative weight of the factors associated with victimization and perpetration of DV among young people and adolescents.

In light of the above, the aim of this study was to conduct a bibliographic review and offer an updated synthesis of the results reported by meta-analyses regarding risk and protective factors for increasing of $\mathrm{DV}$, in accordance with the proposed social-ecological model. A second aim was to draw comparisons between different analysis levels in order to determine the relative weight of each factor in relation to DV. Following the suggestions made in previous studies, different variable types and the perpetration and victimization dimensions were analyzed separately.

\section{Method}

First of all, a review was conducted of all available metaanalyses focusing on DV, in both Spanish and English, in accordance with the PRISMA model (Urrútia \& Bonfill, 2010). The data search was carried out in the following databases: Web of Science, Scopus, Dialnet, PsycInfo and Google Scholar. The search chains in the English databases were constrained to the following terms, in relation to topic, abstract or title: Dating violence and meta-analysis, Dating violence and meta-analytic, Teen Dating Violence and meta-analysis, Teen Dating
Violence and meta-analytic, Courtship and meta-analysis, Courtship and meta-analytic, Dating abuse and meta-analysis, Dating abuse and meta-analytic. The same criterion was used for the search conducted in Spanish.

The review includes those studies that: a) were metaanalyses on DV; b) analyzed the relationship between DV and another variable; and c) featured quantitative measures of DV perpetration and/or victimization. After eliminating duplicates $(N=93)$, a total of 106 studies were identified. $N$ $=91$ were eliminated on the basis of the following criteria: a) they were meta-analyses which did not include DV samples (only married couples or cases of conjugal or domestic violence); b) they included DV and IPV samples together, with no separate analysis; c) they were meta-analyses aimed at analyzing the effectiveness of intervention programs; d) they were primary articles or systematic reviews of DV; or e) they were qualitative studies of DV. $N=15$ studies were finally taken into account, all written in English (See Figure 1).

In this meta-analytical review, the variables associated with DV were grouped in accordance with the socioecological model (Dutton, 1995), with a distinction being made between victimization and perpetration. The individual variables are presented below, followed by the group, family and structural level ones.

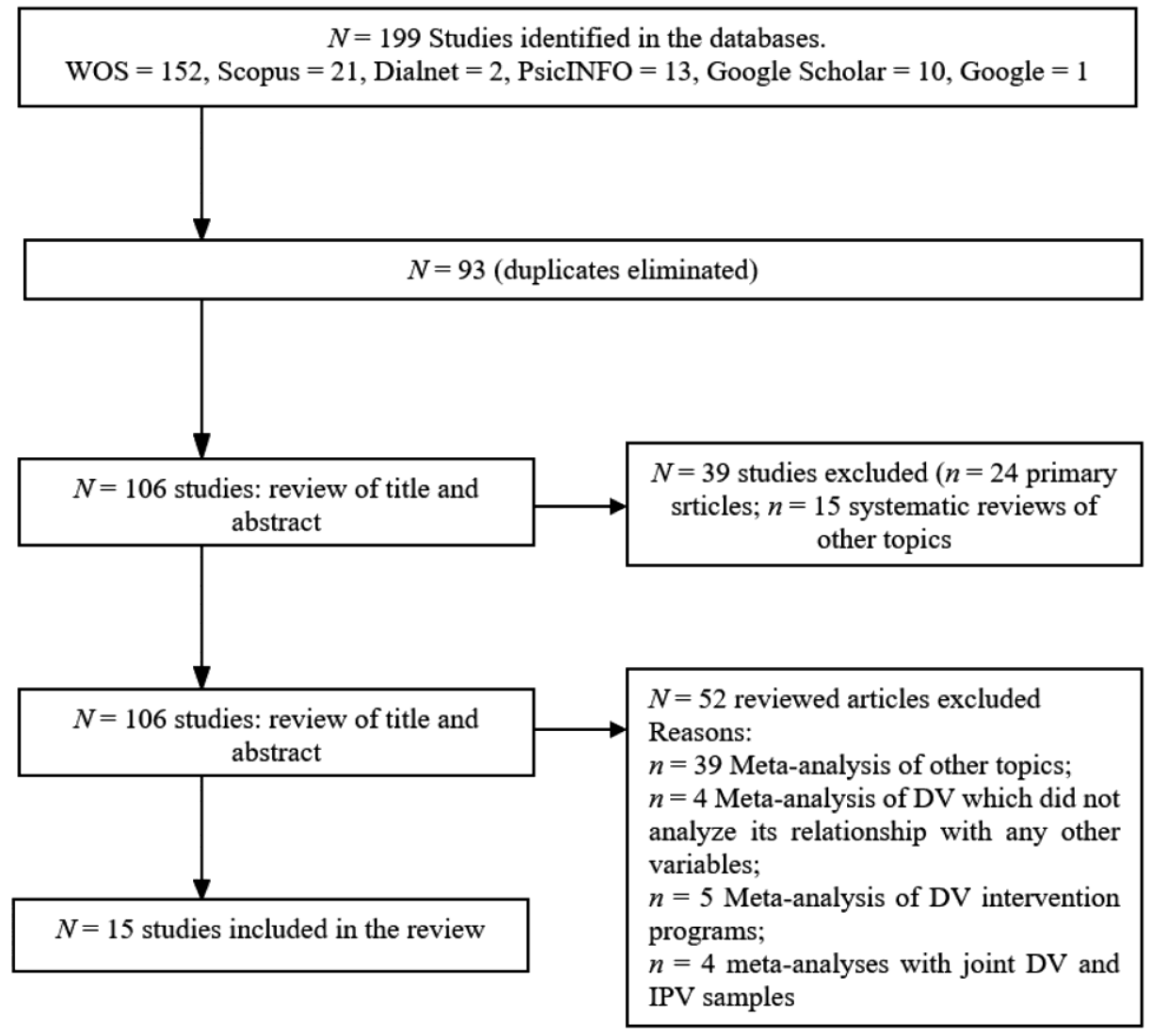

Figure 1. Flow chart: Identification phases and selection process (Urrútia \& Bonfill, 2010). 


\section{Analysis}

The principal results were taken into account for each meta-analysis, along with an effect size calculator ( $d$, odds ratio, risk ratio, $B, r$ and mean $r$. Within each meta-analysis, the statistics $\left(Q_{b}\right)$ that evaluated the influence of potential risk factors on DV were obtained, along with those $\left(Q_{w}\right)$ indicating the degree of heterogeneity within each risk factor category assessed. The confidence intervals (CI) were included, as were the sample size or total number of participants $(N)$, and the number of studies included for each variable $(k)$ (Johnson \& Eagly, 2014).

Population parameters were estimated as Pearson's $r$ correlations, both because they are easy to interpret and because conversion formulas are available for transforming other statistical tests (for example, $F$, $t$, chi-square) into $r$ values (Rosenthal, 1984). $r$ estimates are provided on the basis of the logit transformation (Borenstein, Hedges, Higgins \& Rothstein, 2009). An Excel macro program (Wilson, 2016) designed specifically for use in meta-analyses was used for this purpose.

Whenever possible, the coefficients were converted to Fisher $Z(r)$ values, which are deemed to be closer to normality. $Z r$ values provide information about the mean magnitude of the effect size, in accordance with the size of the final sample included in each meta-analysis (most conservative method) (Field, 2001). In those cases in which the metaanalysis fails to specify the $N$ of each primary study, the $\mathrm{Zr}$ estimate is calculated on the basis of the total $N$ of the sample. Each $Z(r)$ represents the effect size $(r)$ weighted against the size of the sample, in accordance with the method recommended by Rosenthal (1984), taking the product of the $Z(r)$ value and the appropriate degrees of freedom for each study. Studies were weighted in accordance with sample size in order to place greater emphasis on those studies generating results from larger samples, which are assumed to be more representative of the population of interest. Subsequently, following the recommendations of Borenstein et al. (2009), to facilitate the interpretation of the results, each Z(r) was transformed into an $r$. Finally, comparisons were made between the mean $r$ found for each variable, between perpetration and victimization and in accordance with the proposed level-based category system (Cohen, Cohen, West \& Aiken, 2003). In general, $r$ values of around .10 are considered small, values of around .30 are considered medium and values of .50 and above are considered large (Cohen, 1988). In social psychology, the mean $r$ value usually oscillates between .20 and .30 (Hemphill, 2003).

\section{Results}

The $K=15$ studies selected enabled the identification of 18 variables linked to $\mathrm{DV}$, since some studies analyzed more than one variable at the same time. A total of 7 variables were found for the individual level $(38.9 \%), 7$ for the micro level $(38.9 \%), 2$ for the exo level $(11.1 \%)$ and 2 for the macro level $(11.1 \%)$. Despite including both IPV and DV samples, the meta-analyses by Devries (2013a \& 2013b), Madigan, Wade, Tarabulsy, Jenkins and Shouldice, (2014), Moore et al. (2008) and Crane, Hawes and Weinberger (2013) nevertheless presented the results separately for each one, enabling us to extract the specific data pertaining to DV.

The results revealed 66 effect sizes, 41 referring to DV victimization $(62.1 \%)$ and 25 referring to DV perpetration $(37.9 \%)$. In specific terms, 18 effect sizes were identified for individual variables, $(27.3 \%), 38$ for variables linked to the family level $(57.5 \%), 4$ for contextual variables $(6.1 \%)$ and 6 for structural variables $(9.1 \%)$.

Table 1. Risk factors associated with DV at the Ontogenetic (individual) level.

\begin{tabular}{|c|c|c|c|c|c|}
\hline Study & $K$ & $\mathbf{N}$ & Sample (k) & Empirical evidence $^{1}$ & Vict. $r$ Perp. $r$ \\
\hline \multicolumn{6}{|c|}{ Suicide attempt. Victimization: $N=26943, \mathrm{Zr}=.15, \mathrm{CI}[.14, .16], r=.15$} \\
\hline $\begin{array}{l}\text { Devries et } \\
\text { al. (2013a) }\end{array}$ & $\begin{array}{l}16 \\
\mathrm{LS}\end{array}$ & 36163 & $\begin{array}{l}\text { Young } \mathrm{M} \text { and } \mathrm{W} \\
\text { (aged 14-21). } \\
\text { USA }\end{array}$ & $\begin{array}{l}\text { Association between suicide attempts and victimization among } \\
\text { women: } k=1(n=1659), \beta=.12 .95 \% \text { CI }[.02, .22] ; k=1(n=822) \text {, } \\
\text { OR }=3.2,95 \% \text { CI }[.97,103.59] .\end{array}$ & \\
\hline $\begin{array}{l}\text { Castellví et } \\
\text { al. (2016) }\end{array}$ & $\begin{array}{l}29 \\
\mathrm{LS}\end{array}$ & $\begin{array}{l}14373 \\
0\end{array}$ & $\begin{array}{l}\mathrm{M} \text { and } \mathrm{W} \text { (aged } 12-26) \\
\text { General population. } \\
\text { USA }\end{array}$ & $\begin{array}{l}\text { Victims of DV are more likely to attempt suicide in comparison } \\
\text { with non-victims: } k=4(n=24462), O R=1.65,95 \% \text { CI [1.40, } \\
\text { 1.94]. }\end{array}$ & \\
\hline \multicolumn{6}{|c|}{ Adolescent pregnancy. Victimization: $N=20892, Z r=.17, \mathrm{CI}[.16, .18], r=.17$} \\
\hline $\begin{array}{l}\text { Madigan et } \\
\text { al. (2014) }\end{array}$ & $\begin{array}{l}38^{2} \\
10 \\
\text { DV }\end{array}$ & 75390 & $\begin{array}{l}\text { Women aged } 14 \text { - } 18 \text { and } \\
\text { over, pregnant before age } \\
\text { 20. USA (25), Canada (3) } \\
\text { New Zealand (3), Brazil } \\
\text { (2), Ecuador (2), South } \\
\text { Africa (1), Jamaica (1), El } \\
\text { Salvador (1) }\end{array}$ & $\begin{array}{l}\text { Adolescent pregnancy is associated with: Sexual abuse: } k=3(n= \\
4744), \text { total OR }=1.55,95 \% \text { CI }[.88,2.72] .1 \text { st Study }(n=1977), \text { OR } \\
=1.20,95 \% \text { CI }[.50,2.98] ; 2 \text { nd Study }(n=2186), \text { OR }=2.90,95 \% \\
\text { CI [1.44, 5.85]; 3rd Study }(n=581), \text { OR }=1.17,95 \% \text { CI }[.80,1.71] . \\
\text { Physical abuse: } k=4(n=13579), \text { total OR }=1.72,95 \% \text { CI }[1.13 \text {, } \\
\text { 2.62]. } 1 \text { st Study }(n=1977), \text { OR }=1.80,95 \% \text { CI }[1.09,2.97] ; 2 \text { nd } \\
\text { Study }(n=2186), \text { OR }=2,95 \% \text { CI }[1.19,3.37] ; 3 \text { rd Study }(n= \\
328), O R=.96,95 \% \text { CI }[.61,1.52] ; 4 \text { th Study }(n=9088), O R= \\
1.8596,95 \% \text { CI }[1.62,2.11] \\
\text { Adolescent pregnancy is associated with physical/sexual abuse: } k \\
=3(n=2569), \text { OR }=3.83,95 \% \text { CI }[2.963,4.97], Q_{b}=1.08, \text { ns. }\end{array}$ & .12 \\
\hline
\end{tabular}




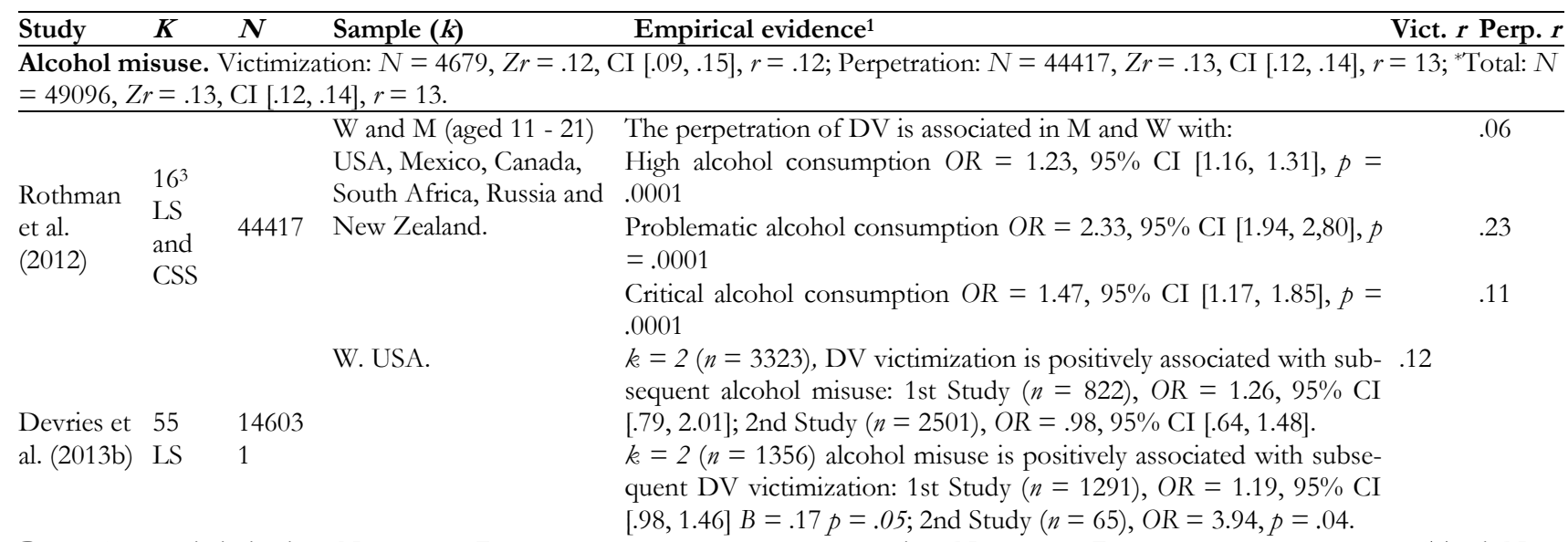

Drug abuse. Victimization: $N=23483, Z r=.12$, CI [.11,.13], $r=12$; Perpetration: $N=97356, Z r=.13, \mathrm{CI}[.12, .14], r=.13$; ${ }^{*}$ Total: $N=$ $120839, \mathrm{Zr}=.13$, CI [.12,.14], $r=13$.

$\mathrm{M}$ and $\mathrm{W}$ (aged 15 and $\quad$ Drug abuse is positively associated with DV perpetration: $k=9(n=$

over). Community, clinicalN/I), W, $d=.28,95 \%$ CI [.24, 31], $Q_{W}=131.89, p<.001$.

and mixed sample. Cauca-

al. (2008) $96 \quad 80000$ sian (43), Black (14), His-

panic (9), Native Ameri-

can and Asian (2), mixed

and N/I (28)

$\mathrm{W}$ and $\mathrm{M}$

Johnson et $\begin{array}{lll}13 & & \text { (aged 11-27) } \\ \text { LS } & 38719 \text { asd }\end{array}$

Marijuana use increases the likelihood of perpetrating physical DV

al. (2017). LSS 38719 USA

by $45 \%:(n=17356), O R=1.45,95 \%$ CI $[1.20,1.76], p=.0001$.

Marijuana use increases the likelihood of being a victim of physical .12

DV by $54 \%:(n=23483)$, OR $=1.54,95 \%$ CI $[1.22,1.93]$.

Cigarette smoking. Victimization: $N=271792, Z r=.20$, CI [.20, .21], $r=.20$.

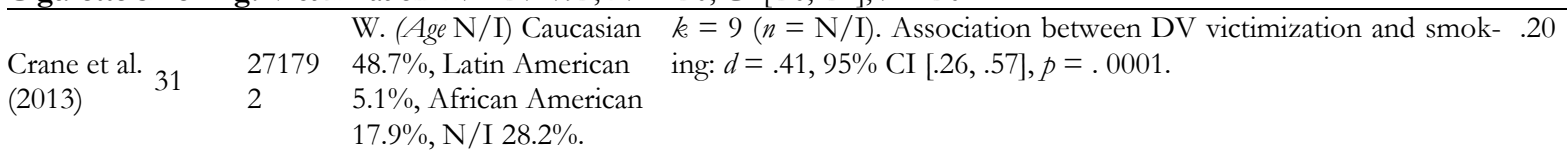

Social desirability. Victimization: $N=435, Z r=-.15$, CI [-.24, -.06], $r=-.15$.

Sugarman $\quad \mathrm{W}$ and M university stu- Low Social Desirability is associated with higher DV reporting, $k=-.15$

\& Hotaling $7 \quad 1964$ dents. $1(n=435)$

can American

Sex. Victimization: $N=334339, Z r=.10$, CI [.10, .10], $r=.10$; Perpetration: $N=334339, Z r=.21$, CI [.21, .21], $r=.21 ;{ }^{*}$ Total: $N=$ 334339, $Z r=.16$, CI [.16,.16], $r=.16$.

$\mathrm{M}$ and $\mathrm{W}$

(aged 13-18).

Sex is associated with physical DV $k=96(n=221221)$. Perpetra- $.05 \quad .18$

tion of physical DV among women is higher $(25 \%)$ than among men $(13 \%) \cdot k=35(\mathrm{n}=\mathrm{N} / \mathrm{I}) \mathrm{W}$ and $k=38 \mathrm{M}(\mathrm{n}=\mathrm{N} / \mathrm{I}) \mathrm{OR}=$ $.51,95 \%$ CI $[.41, .63], p=.0001$.

$\begin{array}{lll}\text { Wincentak } & 101 & 33433 \\ \text { et al. } & \text { CSS } & \end{array}$

et al. CSS 9

No sex differences were found for physical DV victimization (21\%)

$k=62(\mathrm{n}=\mathrm{N} / \mathrm{I}) \mathrm{W}$ and $k=52 \mathrm{M}(\mathrm{n}=\mathrm{N} / \mathrm{I}): \mathrm{OR}=1.18,95 \% \mathrm{CI}$

$[.99,1.40], p=.06$.

Sexual DV perpetration is higher among men (10\%) than among $.15 \quad .25$

women $(3 \%) . k=15 \mathrm{M}$ and $k=13 \mathrm{~W}(\mathrm{n}=\mathrm{N} / \mathrm{I}), \mathrm{OR}=2.54,95 \%$

CI $[2.21,2.92], p=.0001$.

Sexual DV victimization is higher among women: $k=24 \mathrm{~W}$ and $k$

$=17 \mathrm{M}(\mathrm{n}=\mathrm{N} / \mathrm{I}), \mathrm{OR}=.57,95 \% \mathrm{CI}[.41, .79], p=.0001$

$\overline{\mathrm{DV}}=$ Dating violence; $K=$ Number of studies, $k=$ Subsample; LS= Longitudinal studies; CSS: Cross-sectional studies; $N=$ Number of total sample; $n=$ Number of subjects in the subsample; $\mathrm{N} / \mathrm{I}=$ No information (the $r$ was standardized in accordance with the sample total); W= Women; $\mathrm{M}=\mathrm{Men} ; r=\mathrm{Mean}$ effect size; $O R=$ Odds ratio; $R R=$ Relative Risk; $C I=$ Confidence Interval; $Q_{b}=$ Heterogeneity between subgroups; $Q_{\nu}=$ Heterogeneity within the subgroup; ns $=$ Not significant. $95 \% \mathrm{CI}$ for all values in the table. ${ }^{1}$ The studies indicated correspond to the primary studies included in the meta-analysis. ${ }^{2}$ The total N of the study is 38 because it includes Intimate Partner Violence (IPV) and Dating Violence (DV) samples, the data described pertain only to DV studies. ${ }^{3}$ The authors only include $k=16$ cross-sectional studies in the meta-analysis (18 effect sizes); the other longitudinal studies are not included due to their high degree of heterogeneity (total $K=28$ ). *The total $N s$ were calculated by eliminating all duplicate values for victimization, perpetration and per variable. 
At an individual level (see Table 1), two $(k=2)$ metaanalyses found a relationship between DV victimization and subsequent suicide attempts. Devries et al. (2013a) found a positive correlation between suffering from DV and suicide attempts among women, and Castellví et al. (2016) confirmed a higher risk of suicide attempts among young victims of DV (both male and female) than among those who had not been exposed to this type of violence.

One of the meta-analyses explored the relationship between being a victim of DV and adolescent pregnancy. Madigan et al. (2014) analyzed the association between adolescent pregnancy and history of abuse and mistreatment by a family member, partner (IPV) or date (DV) among adolescent and adult women pregnant before age 20. Adolescent pregnancy was found to significantly correlate with physical and sexual abuse, although not with emotional abuse. The concurrent effect of physical and sexual abuse is stronger than for any individual form of abuse, increasing the risk of adolescent pregnancy nearly fourfold.

Five $(k=5)$ of the meta-analyses explored the relationship between DV and substance abuse. In specific terms, $k=$ 2 of the studies focused on alcohol misuse, one in relation to DV perpetration and the other in relation to DV victimization. Moreover, $k=2$ studies analyzed the relationship between DV and drug abuse and $k=1$ study focused on cigarette smoking. As regards alcohol misuse and DV perpetration, Rothman, McNaughton, Johnson \& LaValley (2012) found that higher levels of alcohol misuse (in terms of both frequency and quantity of consumption, and in relation to problematic consumption and critical consumption episodes) were positively associated with DV perpetration. Moreover, alcohol misuse among women was found to be positively associated with DV victimization (Devries et al., 2013b). In relation to drug abuse and DV, the meta-analysis conducted by Moore et al. (2008) found that this behavior was linked to higher levels of dating violence (DV), although a large degree of variability was also observed between the different studies analyzed. Johnson et al., (2017) found an association between marijuana use and physical dating violence perpetration and victimization. No significant differences were observed, however, between victimization and perpetration $\left(r_{v}-r_{p}=.01\right.$, $Z=1.37, p=.17)$. Crane et al. (2013) analyzed the strength of the relationship between victimization and cigarette smoking, finding that DV victims are significantly more likely to smoke than non victims.

The meta-analytic review conducted by Sugarman and Hotaling (1997) analyzed social desirability (SD) and its relationship with DV, finding a significant effect of SD in DV. Specifically, higher DV reporting was found to be linked to lower SD scores.

Moreover, the meta-analysis by Wincentak et al. (2016) analyzed sex differences in this sense, finding that perpetration of physical violence was more prevalent among women than among men, although perpetration of sexual violence was more prevalent among men than among women. Sexual victimization was also found to be higher among women and perpetration $\left(r_{p}\right)$ was more closely associated with sex than victimization $\left(r_{v}\right)\left(\mathrm{r}_{p^{-}} r_{v}=.11, Z=46.13, p=.0001\right)$. This study also analyzed macro variables, although these will be discussed later on.

Table 2. Risk factors associated with DV at the Microsystem level.

\begin{tabular}{|c|c|c|c|c|}
\hline Study & $\mathbf{N}$ & Empirical evidence $^{1}$ & Vict. & Perp. $\mathrm{r} r$ \\
\hline \multicolumn{5}{|c|}{$\begin{array}{l}\text { Deviant peers (problematic/aggressive behavior) Victimization: } N=22139, \mathrm{Zr}=.26, \mathrm{CI}[.25, .27], r=.25 ; \text { Perpetration: } N=11997, \mathrm{Zr} \\
=.26 \text {, CI }[.21, .31], r=.25 ;{ }^{*} \text { Total: } N=31309, \mathrm{Zr}=.26 \text {, CI }[.25, .27], r=.25 \text {. }\end{array}$} \\
\hline $\begin{array}{l}\text { Garthe et } \\
\text { al. (2016) }\end{array}$ & 27 CSS 28491 & $\begin{array}{l}\text { M and W (aged 10-18). Aggressive and antisocial peer behavior is associated with victimiza- } \\
\text { USA (15), Canada (10), tion: } k=5(n=1580), r=.28,95 \% \text { CI }[.20, .35], p=.0001 \text { and per- } \\
\text { Thailand (1) Brazil (1). petration: } k=9(n=9170), r=.19,95 \% \text { CI [.05, .32], } p=.0001\end{array}$ & .28 & .19 \\
\hline $\begin{array}{l}\text { Hérbert et } \\
\text { al. }(2017)\end{array}$ & 278712 & $\begin{array}{l}\text { M and W }(M=19 \text { years Having deviant peers } k=14(n=17732) \text { is associated with victimiza- } \\
\text { old). USA } 72 \% \text {, Canada tion (psychological, physical and/or sexual) } r=.25,95 \% \text { CI }[0.85, \\
\begin{array}{ll}19 \% \text {, Asia } 9 \% & 0.31], p=.0001 .\end{array}\end{array}$ & .25 & \\
\hline $\begin{array}{l}\text { Park \& } \\
\operatorname{Kim}(2018)\end{array}$ & 27 CSS LS 162724 & $\begin{array}{l}\text { M and W (aged 13-22). Deviant peer behavior }(n=2827) \text { is associated with victimization: } \mathrm{Zr} \\
\text { USA (19), Switzerland }=.26,95 \% \text { CI }[0.22,0.30] \text { and perpetration: } Z r=.45,95 \% \mathrm{CI}[0.38 \text {, } \\
\begin{array}{ll}\text { (1), Taiwan (1) and } & 0.52] . \\
\text { Canada (6). }\end{array}\end{array}$ & .26 & .45 \\
\hline \multicolumn{5}{|c|}{$\begin{array}{l}\text { Peer support. Victimization: } N=166651, Z r=-.13 \text {, CI }[-.13,-.13], r=-.13 \text {; Perpetration } N=242, Z r=-.23, \text { CI }[-.35,-.11], r=-.23 ;{ }^{*} \text { Total } \\
N=166651, Z r=-.13 \text {, CI [-.13, -.13], } r=-.13 \text {. }\end{array}$} \\
\hline $\begin{array}{l}\text { Hérbert et } \\
\text { al. (2017) }\end{array}$ & 278712 & $\begin{array}{l}\mathrm{M} \text { and W }(M=19 \text { years Greater peer support } k=10(n=166409) \text { is associated with lower } \\
\text { old). USA } 72 \% \text {, Canada levels of DV victimization (psychological, threats, physical and/or } \\
19 \% \text {, Asia } 9 \% \quad \text { sexual): } Z r=-.13 \text { CI }[-0.21,-0.06], p=.001 .\end{array}$ & -.13 & \\
\hline $\begin{array}{l}\text { Park \& } \\
\text { Kim (2018) }\end{array}$ & $\begin{array}{l}27 \\
\text { CSS LS }\end{array}$ & $\begin{array}{ll}\text { M and W (aged 13-22). } & \text { Strong peer support and positive friendship }(n=242) \text { is associated } \\
\text { USA (19), Switzerland } & \text { with low levels of DV victimization: } Z r=-.29,95 \% \text { CI [-0.42,- } 0.17] \\
\text { (1), Taiwan (1) and } & \text { and low levels of DV perpetration: } Z r=-.23,95 \% \text { CI [0.38, -0.09)] } \\
\text { Canada (6). } & \end{array}$ & -.29 & -.23 \\
\hline
\end{tabular}




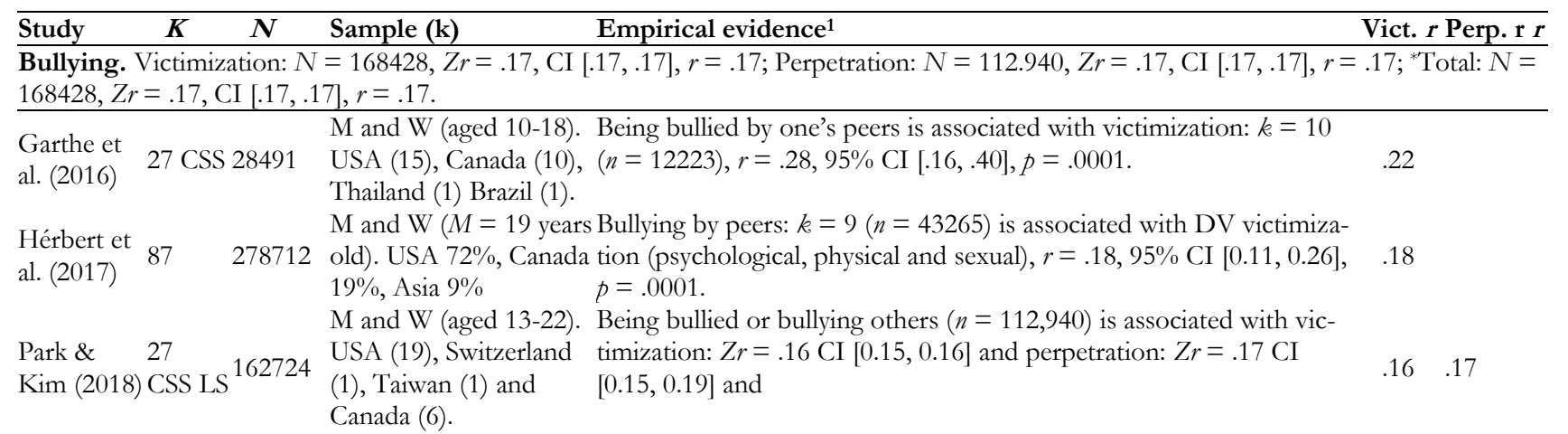

Peer sexual harassment. Victimization: $N=6835, Z r=.29$, CI $[.27, .31], r=.28$

Hérbert et $\quad \mathrm{M}$ and $\mathrm{W}(M=19$ years Peer sexual harassment: $k=5(n=6835)$ is associated with DV vic-

278712 old) USA 72\%, Canada timization (psychological, physical and/or sexual), $r=.29,95 \%$ CI $19 \%$, Asia $9 \% \quad[0.15,0.43], p=.0001$.

Peer dating violence. Victimization: $N=2175, Z r=.28$, CI [.24, .32], $r=.27$; Perpetration: $N=3900, Z r=.29$, CI [.26, .32], $r=.28$; *Total: $N=6075, Z r=.29$, CI [.27, .31], $r=.28$. $\mathrm{M}$ and $\mathrm{W}$ (aged 10-18). DV among one's friends and peer group is associated with DV vic$\begin{aligned} & \text { Garthe et } \\ & \text { al. (2016) }\end{aligned} 27$ CSS 28491 USA (15), Canada (10), timization: $k=8(n=2175), r=.28,95 \%$ CI [.24, .33], $p=.0001$ and
Thailand (1) Brazil (1). DV perpetration: $k=10(n=3900), r=.29,95 \%$ CI [.22, .37], $p=$ .0001 .

Violence in family of origin. Victimization: $N=461057 \mathrm{Zr}=.16$, CI [.16, .16], $r=.16$; Perpetration: $N=55963, \mathrm{Zr}=.13, \mathrm{CI}[.13, .15], r$ $=.13$; ${ }^{*}$ Total: $N=461057, Z r=.16,95 \%$ CI $[.16, .16], r=.16$.

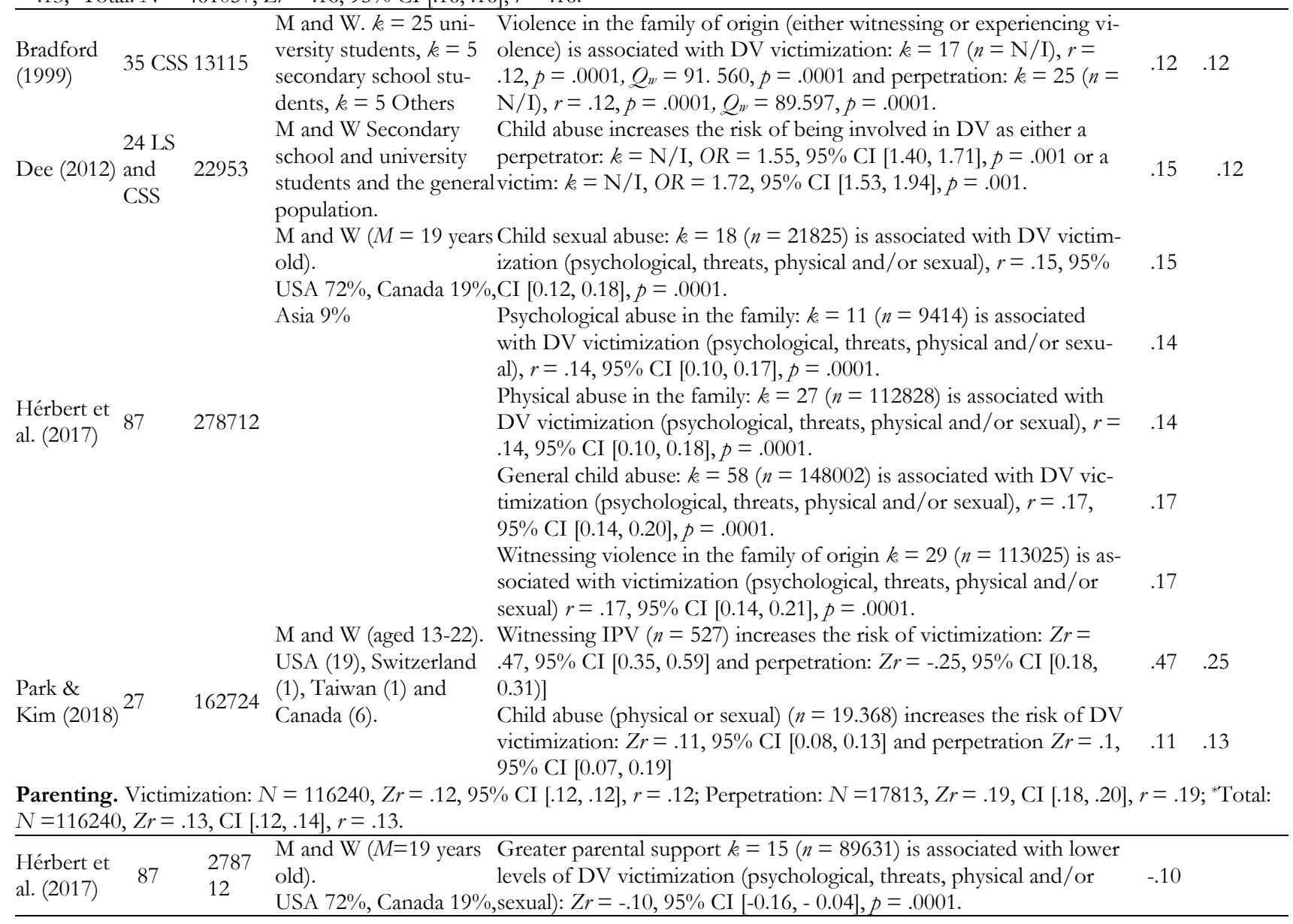




\begin{tabular}{|c|c|c|c|c|c|c|}
\hline \multirow[t]{2}{*}{ Study } & \multirow[t]{2}{*}{$K$} & \multirow[t]{2}{*}{$\mathbf{N}$} & \multirow{2}{*}{$\begin{array}{l}\text { Sample (k) } \\
\text { Asia } 9 \%\end{array}$} & \multirow{2}{*}{$\begin{array}{l}\text { Empirical evidence }^{1} \\
\text { Greater parental control } k=8(n=8796) \text { is associated with lower } \\
\text { levels of DV victimization (psychological, threats, physical and } / \text { or } \\
\text { sexual): } Z r=-.12,95 \% \text { CI }[-0.22,-0.02], p=.012 \text {. }\end{array}$} & \multicolumn{2}{|c|}{ Vict. $r$ Perp. $\mathrm{r} r$} \\
\hline & & & & & -.12 & \\
\hline \multirow{4}{*}{$\begin{array}{l}\text { Park \& } \\
\text { Kim (2018) }\end{array}$} & \multirow{4}{*}{27} & \multirow{4}{*}{$\begin{array}{l}1627 \\
24\end{array}$} & $\begin{array}{l}\text { M and W (aged 13-22). } \\
\text { USA (19), Switzerland } \\
\text { (1), Taiwan (1) and }\end{array}$ & $\begin{array}{l}\text { Negative parenting }(n=6932) \text { increases the risk of } \mathrm{DV} \text { as both vic- } \\
\text { tim: } Z r=.23,95 \% \mathrm{CI}[0.18,0.28] \text { and perpetrator: } Z r=-.21,95 \% \mathrm{CI} \\
[0.15,0.27)]\end{array}$ & .23 & .21 \\
\hline & & & Canada (6). & $\begin{array}{l}\text { High levels of positive parenting }(n=8455) \text { are associated with low } \\
\text { levels of DV victimization: } Z r=-.17,95 \% \text { CI }[-0.22,--0.12] \text { and low }\end{array}$ & -.17 & -.15 \\
\hline & & & & $\begin{array}{l}\text { Family relationship problems }(n=527) \text { increase the likelihood of DV } \\
\text { victimization: } Z r=.35,95 \% \text { CI }[0.28,0.43] \text { and DV perpetration: } Z r \\
=.35,95 \% \text { CI }[0.25,0.45] .\end{array}$ & .35 & .35 \\
\hline & & & & $\begin{array}{l}\text { Fear of violence in the family }(n=1899) \text { is associated with DV vic- } \\
\text { timization: } Z r=.24,95 \% \text { CI }[0.16,0.31] \text { and DV perpetration: } Z r= \\
.21,95 \% \text { CI }[0.13,0.30] \text {. }\end{array}$ & .24 & .21 \\
\hline
\end{tabular}

$\mathrm{DV}=$ Dating violence; $K=$ Number of studies, $k=$ Subsample; LS= Longitudinal studies; CSS: Cross-sectional studies; $N=$ Number of total sample; $n=$ Number of subjects in the subsample; N/I=No information (the $r$ was standardized in accordance with the sample total); W= Women; M= Men; $r=\mathrm{Mean}$ effect size; $O R=$ Odds ratio; $C I=$ Confidence Interval; $Q_{w}=$ Heterogeneity within the subgroup. ${ }^{1}$ (sum of the Ns of each primary study). $95 \%$ CI for all values in the table. ${ }^{1}$ The studies indicated correspond to the primary studies included in the meta-analysis. ${ }^{*}$ The total $N s$ were calculated by eliminating all duplicate values for victimization, perpetration and per variable.

Secondly, in relation to group (or microsystem) variables (see Table 2), three $(k=3)$ studies analyzed the relationship between DV and the peer group. The meta-analytic review conducted by Garthe, Sullivan and McDaniel (2016) found an association between DV and aggressive and antisocial peer behaviors, being victimized by one's peers (bullying) and peer DV (i.e. DV among the peer group), although it does not specify the specific type of DV involved (physical, psychological or sexual). The study by Hérbert et al. (2017) concluded that affiliation with deviant peers, peer victimization and peer sexual harassment (i.e. sexual harassment by peers) predicted greater degrees of DV (physical, threats, psychological and sexual), while support from peers was negatively associated with DV. Finally, Park and Kim (2018) found an association between having deviant peers, suffering from bullying or being a bully (physical, psychological and/or cyberbullying) and DV. Moreover, the factor found to best predict DV perpetration was having peers with problematic behavior. On the other hand, a high level of positive friendship was found to negatively correlate with both DV perpetration and DV victimization.

Also at the microsystem level, four $(k=4)$ studies analyzed the influence of family on DV. Bradford (1999) found a weak association between violence in the family of origin (defined as either having directly witnessed or experienced violence at home) and DV. Dee (2012) also found that child abuse in the family increased the risk of becoming involved in DV as either an aggressor or a victim. Similarly, Hérbert et al. (2017) analyzed different types of child abuse in the family of origin and their relationship with DV, finding that sexual, psychological and physical child abuse, as well as neglect and witnessing intimate partner violence between parents, were all risk factors for becoming a victim of DV. Moreover, these authors also analyzed protective factors for DV, finding that parental support and supervision were negatively associated with DV. A little later, Park and Kim (2018) broad- ened the analysis of family variables to include DV victimization and perpetration, finding that witnessing violence between one's parents is a strong predictor of DV victimization. Moreover, negative parenting (rejection of one's children, inconsistent discipline), family problems (fights, hurtful behavior) fear of violence in the family and child abuse (physical, psychological or sexual abuse by parents) were all found to be positively linked to DV, while positive parenting (communication and parental support) was negatively associated with this phenomenon.

Thirdly, in relation to contextual variables (exosystem), two $(k=2)$ studies analyzed the variables age and residential neighborhood (see Table 3). Wincentak et al. (2016) found that mean age did not predict significant prevalence rates of physical violence during courtship. Nevertheless, the mean age of the sample did predict a greater risk of sexual DV victimization among both sexes. Also, the meta-analytical review conducted by Park and Kim (2018) found that living in violent neighborhoods with a high level of ethnic heterogeneity was linked to higher levels of both perpetration and victimization, with the association with victimization being stronger. Moreover, when these authors analyzed the influence of residential neighborhood on DV, they found that high support in the neighborhood was negatively associated with DV perpetration and victimization.

Fourthly, in relation to the variables associated with the macrosystem, the results reported by Wincentak et al. (2016) indicate that belonging to a cultural minority, i.e. belonging to any cultural group that is not the dominant group of one's country of origin, was associated with DV perpetration and victimization, but only among women, while living in an economically disadvantaged region predicted greater risk of perpetrating and suffering physical DV among both women and men. This last finding was also confirmed by the metaanalysis carried out by Park and Kim (2018), which found 
that socioeconomic status was negatively associated with DV perpetration and victimization.

The analysis of the differences between effect sizes for perpetration and victimization revealed significant differences in total effect for individual (ontogenetic) variables, with the $r$ effect size being small and lower for victimization $(r=.15)(N=682563)$ than for perpetration $(r=.19)(N=$ 476112) $\left(r_{v^{-}} r_{p}=-.04, Z=-21.82, p=.0001\right)$. Smoking and adolescent pregnancy, along with attempted suicide and social desirability, were found to correlate with a higher risk of DV victimization, with a small effect. Alcohol misuse, drug abuse and sex were also found to be associated with DV victimization, although with a smaller effect. Sex had a larger effect in relation to perpetration than in relation to victimization $\left(r_{v^{-}} r_{p}=-.11, Z=-46.13, p=.0001\right)$, although the difference was small. No differences were observed between perpetration and victimization in relation to alcohol misuse $\left(r_{v^{-}} r_{p}=-.01, Z=-.66, p=.51\right)$ or drug abuse $\left(r_{v^{-}} r_{p}=-.01, Z\right.$ $=-1.39, p=.16$ ) (see Table 1). The difference between the $r \mathrm{~s}$ for these two variables was not relevant.

At the micro level, significant differences were observed for the total effect of the variables, with the $r$ being smaller for victimization $.15(N=943525)$ than for perpetration .17 $(N=202855)\left(r_{v^{-}} r_{p}=-.02, Z=-14.76, p=.0001\right)$. Nevertheless, the effect size of this difference was small $(<.10)$. Peer sexual harassment was found to have the largest effect size in relation to DV victimization, followed by peer DV. Moreover, peer DV had the largest effect size in relation to aggression, and no significant differences were observed between victimization and perpetration $\left(r_{v^{-}} r_{p}=-.01, Z=-.40, p\right.$
$=.68)$. The variables deviant peers and bullying were found to be associated with both DV victimization and perpetration, with the same effect size being found for both measures. Social support from peers was associated with both perpetration and victimization, with the difference not reaching statistical significance $\left(r_{v}-r_{p}=-.10, Z=-1.60, p=\right.$ .11). As regards violence in the family of origin, significant differences were found between DV perpetration and victimization $\left(r_{v^{-}} r_{p}=-.03 Z=-14.63, p=.0001\right)$, with the effect size being slightly larger for victimization. As regards parenting, the effect size was larger for DV perpetration $\left(r_{v^{-}} r_{p}=\right.$ $.07, Z=-8.92, p=.0001)$, although this difference was not found to be relevant. Some effect sizes were found to be low at the micro level. Violence in the family of origin, parenting and bullying had effect sizes of between .12 and .19, while peer sexual harassment, peer DV, deviant peers and peer support had larger effect sizes, ranging between .23 and .28 (see Table 2).

At the exosystem level, the difference between victimization $r=.51(N=336677)$ and perpetration $(N=2338) r=$ .13 was significant $\left(r_{v}-r_{p}=.43, Z=20.50, p=.0001\right)$ and moderate, with the larger effect size being found for victimization. In cases of victimization, age was associated with (sexual) DV, with a medium effect size, although this association was not observed in cases of perpetration. Neighborhood, on the other hand, was found to have a small effect size. Moreover, a significant (although not relevant) difference was observed between victimization and perpetration $\left(r_{v^{-}} r_{p}=.09, Z=0.03, p=.0001\right)$, with the effect size being higher in relation to the former (see Table 3 ).

Table 3. Risk factors associated with DV at the Exosystem and Macrosystem levels:

\begin{tabular}{|c|c|c|}
\hline Study $\quad K$ & Sample $(k)$ & Empirical evidence ${ }^{1}$ \\
\hline \multicolumn{3}{|l|}{ Exosystem } \\
\hline \multicolumn{3}{|c|}{ Age. Victimization: $N=334339, Z r=.51,95 \%$ CI $[.51, .51], r=.47$} \\
\hline $\begin{array}{l}\text { Wincentak } \\
\text { et al. } \quad \text { CSS } \\
\text { (2016) }\end{array}$ & $\begin{array}{c}\text { M and W } \\
\text { 334339 } \\
\text { Aged between 13-18. }\end{array}$ & $\begin{array}{l}\text { The older the informant the greater the risk of sexual DV: men } k= \\
13(n=\mathrm{N} / \mathrm{I}), B=2.00,95 \% \mathrm{CI}[1.19,3.35], p=.01, Q w=21.69, p .51 \\
=.05 \text {; women } k=17(n=\mathrm{N} / \mathrm{I}), B=1.96,95 \% \mathrm{CI}[1.30,2.96], p= \\
.001, \mathrm{Qw}=24,51 .\end{array}$ \\
\hline
\end{tabular}

Residential neighborhood. Victimization: $N=2338, \mathrm{Zr}=.22$, CI [.18, .26], $r=.22$; Perpetration: $N=2338, \mathrm{Zr}=.13 \mathrm{CI}[.09, .17], r=.13$; *Total: $N=2338, \mathrm{Zr}=.17$, CI $[.13, .21], r=.17$.

Park \& $\quad$ M and W (aged 13-22). Living in a violent neighborhood $(n=2338)$ increases DV victimi-

Kim USA (19), Switzerland (1), zation: $\mathrm{Zr}=.22,95 \% \mathrm{CI}[0.18,0.26]$ and DV perpetration: $\mathrm{Zr}=.22$

(2018) $27 \quad 162724$ Taiwan (1) and Canada (6). .13, 95\% CI [0.07, 0.19].

High support in one's neighborhood $(n=2338)$ is associated with lower levels of DV perpetration: $Z r=.08,95 \%$ CI [-0.12, -0.04].

Macrosystem:

Economic disadvantage. Victimization: $N=335088, \mathrm{Zr}=.08, \mathrm{CI}[.08, .08], r=.08$; Perpetration: $N=335.088, \mathrm{Zr}=.10, \mathrm{CI}[.10, .10], r=$ $.10 ;{ }^{*}$ Total: $N=335088, \mathrm{Zr}=.09$, CI $[.09, .09], r=.09$.

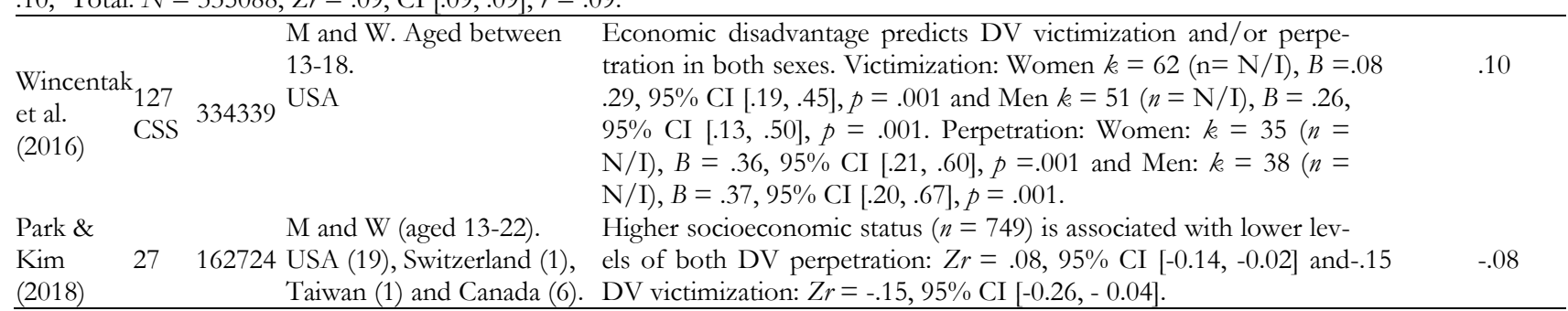




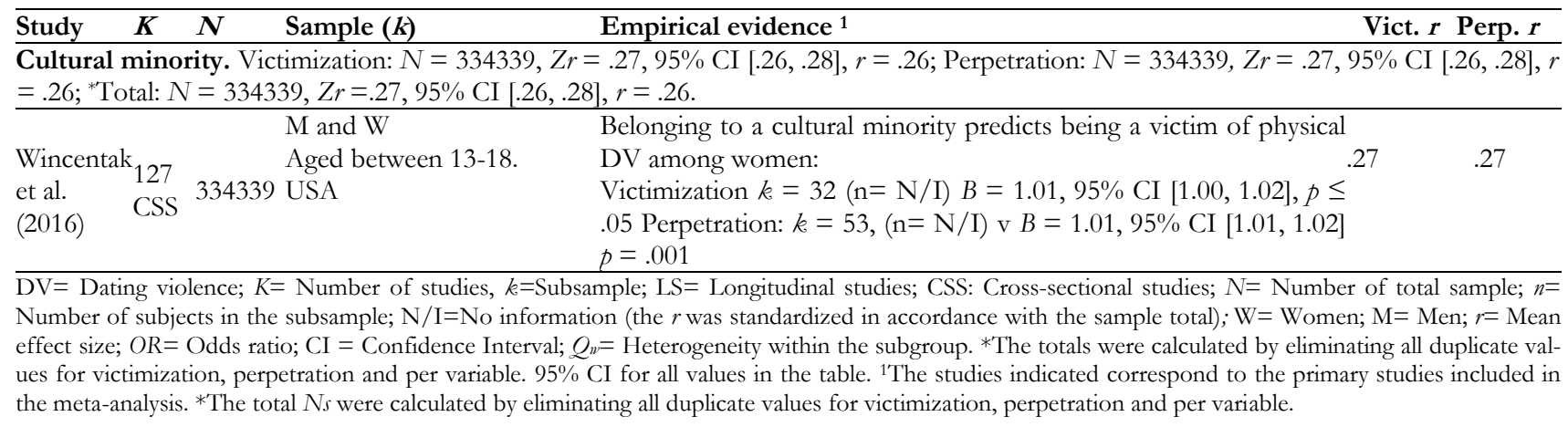

At the macro level, significant differences were found in the total effect size between victimization $(r=.17, N=$ $335088)$ and perpetration $(r=.18, N=335088)\left(r_{v}-r_{p}=-.01\right.$, $Z=-4.22, p=.0001)$, with a small effect size. The association between economic disadvantage and victimization and perpetration was low, and a significant but weak difference was found between the two groups $\left(r_{v^{-}} r_{p}=-.02, Z=-11.12\right.$, $p=.0001)$. A low-to-moderate association was found between belonging to a cultural minority and DV victimization and perpetration, with no differences being found between the two groups (see Table 3).

Overall, we found that the effect size for exosystem variables was large (Level 3, $N=336677, r_{3}=.51$ ) and indeed was larger than for the rest of the levels, all of which had similar effect sizes: macro (Level $4, N=335088, r_{4}=.18$ ), individual (Level 1, $N=824336, r_{1}=.17$ ) and micro (Level $\left.2, N=956595, r_{2}=.16\right)$. The $r$ comparisons revealed significant differences between the macro and exo $\left(r_{4}-r_{3}=.36, Z=\right.$ $-156.03, p=.0001)$, macro and micro $\left(r_{4}-r_{2}=.02, Z=10.25\right.$, $p=.0001)$ and macro and individual levels $\left(r_{4}-r_{1}=.01, Z=\right.$ $5.05, p=.0001)$. Similar differences were also found between the exo and micro $\left(r_{3}-r_{2}=.38, Z=200.28, p=.0001\right)$, exo and individual $\left(r_{3}-r_{1}=.37, Z=191.19, p=.0001\right)$ and micro and individual levels $\left(r_{1}-r_{2}=.01, Z=6.84, p=.0001\right)$. A large difference was observed in effect size between the exo level and the other three levels and significant differences were also found in total effect size between perpetration $(r=$ $.18, N=682054)$ and victimization $(r=.21, N=1629175)$ $\left(r_{1}-r_{2}=-.03, Z=-21.63, p=.0001\right)$.

\section{Discussion}

The 15 meta-analytical studies included in this review describe and group together the factors associated with DV in accordance with the ecological model, thus reaffirming this structure as a valid means of describing the DV risk and protective factors analyzed. In this review, the variables which explain DV (victimization and perpetration) are divided across four levels (ontogenetic or individual, microsystem, exosystem and structural macrosystem).

At the individual level, the variables were found to have a small effect size in relation to DV. A strong association was observed between DV victimization and cigarette smoking, adolescent pregnancy, suicide attempts and social desirability, along with a weaker correlation between victimization and drug abuse and sex. Sex and, to a lesser extent, alcohol misuse and drug abuse were linked to DV perpetration. The results indicate that DV victims are more likely to smoke than non victims. It may be that victims use nicotine as a maladaptive coping strategy associated with a reduction of the negative affect and anxiety linked to DV, as well as other stress-related factors (Crane et al., 2013). Other types of consumption linked to DV (albeit to a lesser extent) include alcohol misuse and drug abuse. Alcohol misuse is associated with both DV perpetration and victimization. Nevertheless, the studies included in the review report certain limitations linked to alcohol misuse measures and the type of design used, which was mainly experimental or laboratory-based. Experimental studies may have little external validity, and longitudinal studies fail to clarify the time direction of the association observed between alcohol misuse and victimization (Devries et al., 2013b). As for drug abuse, the results confirm a weak association between this variable and DV perpetration. Marijuana use is linked to both physical DV perpetration and victimization. It may be that marijuana consumption is a consequence of DV, and is used as a means of coping with anxiety. It may also be linked to a high-risk social environment, in which the purchase and use of drugs may prompt individuals to either become victims of or perpetrate more violence (Bean, 2001). Nevertheless, some authors suggest that drug use and abuse may also serve to disinhibit violent behavior (Ferrer Pérez \& Bosch Fiol, 2005).

Adolescent pregnancy was found to be associated with a history of abuse among teenage girls, and particularly with the concurrence of physical and sexual violence. This result is consistent with those reported by previous reviews, in which unwanted adolescent pregnancy was identified as a variable linked to DV victimization (Joly \& Conolly, 2016; Vezina \& Hebert, 2007).

Sex is also related to DV, and was found to have a greater influence over perpetration than over victimization, although the association was fairly weak. Prevalence rates for physical DV perpetration were higher among women than among men, while the reverse was found to be true for sexual DV perpetration, with the rate being higher among men than among women (Wincentak et al., 2016). Nevertheless, this 
finding is not consistent with the results of the systematic review conducted by Jennings et al. (2017), which found that women in all age groups reported higher prevalence rates of victimization than men. The studies revealed that the type of sample, measurement instrument, reactive violence among women and severity of abuse influenced violence reporting rates among women (Joly \& Conolly, 2016; Wincentak et al., 2016). Another variable found to influence DV reporting is social desirability, which was found to increase violence underreporting among victims (Sugarman \& Hotalling, 1997). One possible explanation for this underreporting may be linked to the stigma associated with being a victim of violence, which has been widely documented in the adult population (Joly \& Conolly, 2016; Puente-Martínez, 2017). Suicide attempts are also linked to victimization among young people (Castellví et al., 2016), as well as with being a woman (Devries, 2013a), although only a few studies include male samples also (Devries, 2013a). This finding is important, since in both Spain and Europe in general, most suicides occur between the ages of 15 and 25. It is therefore a problem with a high youth mortality rate.

At the microsystem level, peer sexual harassment and peer dating violence were found to be the strongest predictors of DV. One of the studies found a significant moderation effect of gender on the relationship between peer sexual harassment and DV, with the effect being higher among women (Hérbert et al., 2017). Moreover, having deviant peers and being bullied by peers (physical or psychological bullying or cyberbullying) increase the likelihood of both DV perpetration and victimization. Nevertheless, peer support was found to reduce the likelihood of being either victim or perpetrator, thereby suggesting that not having a positive social support network in one's immediate environment increases the risk DV. These results confirm that peers are one of the most influential socializing agents during adolescence, for both prosocial behavior (Steinberg, 2014) and violent behavior (Miller-Johnson \& Costanzo, 2004). Moreover, among the family variables studied, having suffered from different types of violence in one's family of origin (physical, sexual or psychological child abuse or witnessing violence between one's parents) is linked to DV. Problematic family relations, negative parenting and fear of violence in the family all increase the risk of DV for both victims and perpetrators, although this effect is fairly weak. On the other hand, greater parental support and control reduce (albeit only slightly) the likelihood of both suffering and perpetrating abuse.

At the exosystem level, age is strongly associated with sexual DV. Indeed, the largest effect size found in the model was for this association. As in previous studies, in this review also age was treated as a contextual variable within the ecological model (Puente-Martínez, Ubillos-Landa, Echeburúa y Páez-Rovira, 2016). One possible explanation for this finding may be that in DV, abuse becomes more frequent and severe over time, with a progressive scaling up of violence levels occurring as those involved grow older (William \& Frieze, 2005; Walker, 1989). Moreover, sexual behaviors tend to ap- pear more frequently during the late teen years (ages 17-19) than during early adolescence (ages 10-14), since it is during this later stage that sexual relations and practices become more frequent among young people (INJUVE, 2016; Eaton et al., 2010). From this perspective, it is more likely for sexual violence to occur among older adolescents and young adults. In this sense, the study by Smith, White and Holland (2003) found that during adolescence, the most common form of sexual victimization is coercive verbal sexual aggression, while among older university students it is more common to find more serious forms of violence, such as rape. It is also important to bear in mind that the studies included in this review were all based on broad definitions of sexual violence encompassing a wide range of behaviors (unwanted kisses or fondling, threatening behavior, etc.) (Wincentak et al., 2016). Living in a violent neighborhood was found to be positively related to DV perpetration and victimization, while support from the community was negatively associated with DV victimization, thus confirming that social-community support may be a protective factor against dating violence. The variables analyzed (violent neighborhood and age) are more closely linked to being a victim of DV than to perpetrating this kind of violence.

Finally, at the macrosystem level, belonging to a cultural minority within one's country of origin is associated among women with physical violence victimization and perpetration (Foshee et al., 2008; Teitelman, Ratcliffe, McDonald, Brawner \& Sullivan, 2011). These results highlight the importance of taking social and cultural context into account when attempting to explain DV. Both victimization and perpetration rates among women belonging to cultural minorities have been linked to extremely violent contexts, exclusion, discrimination and other geographical factors such as region and poverty (Carbone-López, 2013; Wincentak et al., 2016). The relationship between victimization and belonging to a cultural minority was not confirmed in the case of men. Economic disadvantage, on the other hand, was found to increase the risk of perpetration and victimization among both sexes. Although the effect size was very small, previous studies have concluded that poorer regions are those with the highest levels of DV victimization and perpetration among teens (Gressard, Swahn \& Tharp, 2015).

Finally, when the differences between the various levels are analyzed, the results reveal that the exosystem variables have a large effect size that is greater than the effect sizes found for the macro, individual and micro levels, which were all similar and fairly low. This confirms that factors basically related to age, but also to the social-community environment, are those most closely related to DV, as opposed to individual factors or those pertaining to the subject's more immediate or macro environment. In other words, the exosystem variables were the most relevant for explaining DV victimization and perpetration. Although Cohen's criterion was applied in this study, based on reviews of meta-analytical studies (Gignac \& Szodorai, 2016; Richard, Bond \& StokesZoota, 2003) in which the authors recommend considering 
correlations of $.10, .20$ and .30 to be small, typical and relatively large (respectively), we can conclude that the macro, micro and individual levels have a near-to-average effect size (.18-.16). Moreover, it is important to highlight the effect size of certain variables, such as belonging to a cultural minority at the macro level, and peer sexual harassment, peer DV and aggressive peer behavior at the micro level, the effect sizes of which can be considered moderate-to-large. Individual variables were found to have a smaller yet significant effect size in the studies analyzed, indicating that their influence on DV is more limited.

This study has a number of limitations. Firstly, the samples analyzed for the different risk factors were very large, and care must therefore be taken not to overestimate the $r$ size and the inter-group and inter-level differences (Borenstein et al., 2009). Secondly, the results obtained are mainly limited to the population of North America. It would therefore be interesting to carry out further studies in other regions such as Latin America and Europe. Possible moderation effects should also be analyzed in accordance with region and culture. The third limitation is that not all the studies specified the relationships between risk and protective factors and different types of DV. Finally, some metaanalytical studies reporting an association between DV and other variables such as negative emotions $(r=.25)$ (Birkley \& Eckhardt, 2015) and depression ( $r=.17)$ (Beydoun, Beydoun, Kaufman, Lo \& Zonderman, 2012; Devries et al., 2013a) were excluded from the review, because they included joint teen DV and adult IPV samples, with no separate analysis.

Despite these limitations, however, one of the strengths of this study that it systematizes meta-analytical research on the main variables associated with DV, as well as some of the principal risk and protective factors associated with the phenomenon, considering perpetration and victimization separately. Moreover, it is the first systematic review carried out of DV which takes into account all the variables analyzed in previous meta-analyses based on the ecological model. This information complements the results reported by previous reviews on DV and enables us to distinguish between the

\section{References}

Amor, P. J., Echeburúa, E., de Corral Gargallo, P., Sarasua, B. \& Zubizarreta, I. (2001). Maltrato físico y maltrato psicológico en mujeres víctimas de violencia en el hogar: un estudio comparativo. Revista de psicopatología y psicología clínica, 6, 167-178. doi:10.5944/rppc.vol.6.num.3.2001.3913

Bean, P. (2001). Violence and substance abuse. In G. F. Pinard \& L. Pagini (Eds.), Clinical Assessment of Dangerousness: Empirical contributions (pp. 216-237). New York, USA: Cambridge University Press.

Black, M.C., Basile, K.C., Breiding, M.J., Smith, S.G., Walters, M.L., Merrick, M.T., Chen, J. \& Stevens, M.R. (2011). The National Intimate Partner and Sexual Violence Survey (NISVS): 2010 Summary Report. Atlanta, GA: National Center for Injury Prevention and Control, Centers for Disease Control and Prevention

Beydoun, H. A., Beydoun, M. A., Kaufman, J. S., Lo, B. \& Zonderman, A. B. (2012). Intimate partner violence against adult women and its association with major depressive disorder, depressive symptoms and post- characteristics of DV at different levels (onto, micro, exo and macro), clearly defining it as a separate problem from intimate partner violence in adult couples.

One of the main practical implications of the findings reported is that they enable a distinction to be made between variables in terms of their capacity to predict DV perpetration and victimization. Moreover, it suggests that greater efforts should be made in the field of prevention, through early intervention programs aimed at teenagers and the clinical care provided to young women at risk of becoming DV victims. Within the clinical environment, the results suggest that more work should be done with the adolescent population to prevent suicide attempts, teenage pregnancy and drug abuse. Greater efforts also need to be made to prevent violence in the future, given that DV victimization among teenage girls strongly predicts victimization during adulthood (Shorey et al., 2008). The results of the study also suggest that a violent environment and peer support are relevant factors to bear in mind during any intervention aimed at preventing DV. They also enable possible at-risk groups to be identified so that culturally-sensitive interventions can be designed and macrosystem vulnerabilities can be taken into account. Finally, the findings suggest that the social and community support perceived by young people may be a protective factor at the exo level, particularly among women from cultural minorities.

Future research may wish to analyze how these risk factors are interrelated, and to study their accumulative effects. Similarly, it would be interesting to analyze the differences observed in accordance with sample type and to conduct cross-cultural studies that may provide greater insight into the characteristics and specificities of DV and how it differs from IPV. DV forms part of a dynamic systems of influences, and as such, any attempt to mitigate or reduce it requires a dynamic, multi-factor approach that takes into consideration risk factors at all levels (ecological model), as well as their possible interactions. In short, the results obtained confirm prior findings which indicate that DV is a relevant topic of research, due to the magnitude and consequences of the problem.

partum depression: a systematic review and meta-analysis. Social science \& medicine, 75, 959-975. doi:10.1016/j.socscimed.2012.04.025

Birkley, E. L. \& Eckhardt, C. I. (2015). Anger, hostility, internalizing negative emotions, and intimate partner violence perpetration: A metaanalytic review. Clinical psychology review, 37, 40-56. doi:10.1016/j.cpr.2015.01.002

*Bradford, S. (1999). Intergenerational Transmission of Courtship Violence: $\mathrm{AMe}$ ta-Analysis. (Unpublished doctoral dissertation). Faculty of the Virginia Polytechnic Institute \& State University. Retreived from: https://www.researchgate.net/profile/Sandra_Stith/publication/2648 50845_INTERGENERATIONAL_TRANSMISSION_OF_COURT SHIP_VIOLENCE_A_META-

ANALYSIS_By/links/5486005a0cf2ef34478bf0a3/INTERGENER ATIONAL-TRANSMISSION-OF-COURTSHIP-VIOLENCE-AMETA-ANALYSIS-By.pdf 
Borenstein, M., Hedges, L.V., Higgins, J.P.T \& Rothstein, H.R (2009). Introduction to meta-analysis. Chichester, UK: Wiley.

Bosch Fiol, E. \& Ferrer Pérez, V. A. (2012). Nuevo mapa de los mitos sobre la violencia de género en el siglo XXI. Psicothema, 24(4), 548-554

Bosch Fiol, E. \& Ferrer Pérez, V. A. (2013). Nuevo modelo explicativo para la violencia contra las mujeres en la pareja: el modelo piramidal y el proceso de filtraje. Asparkia, 24, 54-67.

Carbone-López, K. (2013). Across racial/ethnic boundaries: Investigating intimate violence within a national sample. Journal of Interpersonal Violence, 28, 3-24. doi: 10.1177/0886260512448850

*Castellví, P., Miranda-Mendizábal, A., Parés, Badell, O., Almenara, J., Alonso, I., Blasco, M. J., Cebrià, A., Gabilondo, A., Gili, M., Lagares, C., Piqueras, J.A., Roca, M., Rodríguez-Marín, J., Rodríguez-Jimenez, T., Soto-Sanz, v Alonso, J. (2016). Exposure to violence, a risk for suicide in youths and young adults. A meta-analysis of longitudinal studies. Acta psychiatrica Scandinavica, 135, 195-211. doi: 10.1111/acps.12679

Cohen, J. (1988), Statistical Power Analysis for the Behavioral Sciences, $2^{\text {nd }}$ Edition. Hillsdale, N.J.: Lawrence Erlbaum.

Cohen, J., Cohen, P., West, S. G. \& Aiken, L. S. (2003). Applied Multiple Regression/Correlation Analysis for the Behavioral Sciences. Mahwah, NJ: Erlbaum.

Cyr, M., McDuff, P. \& Wright, J. (2006). Prevalence and predictors of dating violence among adolescent female victims of child sexual abuse. Journal of Interpersonal Violence, 21, 1000-1017. doi: $10.1177 / 0886260506290201$

Cornelius, T. \& Resseguie, N. (2007). Primary and secondary prevention programs for dating violence: A review of the literature. Aggression and Violent Behavior, 12, 364-375. doi: 10.1016/j.avb.2006.09.006

*Crane, C. A., Hawes, S. W. \& Weinberger, A. H. (2013). Intimate partner violence victimization and cigarette smoking: A meta-analytic review. Trauma, Violence, \& Abuse, 14, 305-315. doi: $10.1177 / 1524838013495962$

*Dee, T. C. (2012). A meta-analysis on the relationship between child maltreatment and dating violence in adolescence and young adulthood (Unpublished doctoral dissertation). University of Washington, Seattle. Retreived from https://digital.lib.washington.edu/researchworks/handle/1773/20667

*Devries, K. M., Child, J. C., Bacchus, L. J., Mak, J., Falder, G., Graham, K., Watts, C. \& Heise, L. (2013b). Intimate partner violence victimization and alcohol consumption in women: a systematic review and meta-analysis. Addiction Review, 109, 379-391. doi:10.1111/add.12393

*Devries, K. M., Mak, J. Y., Bacchus, L. J., Child, J. C., Falder, G., Petzold, M., ... \& Watts, C. H. (2013a). Intimate partner violence and incident depressive symptoms and suicide attempts: a systematic review of longitudinal studies. PLoS Med, 10, e1001439. doi: 10.1371/journal.pmed.1001439

Dutton, D. G. (1995). The domestic assault of women: Psychological and criminal justice perspectives. Vancouver, BC: UBC Press.

Eaton, D. K., Kann, L., Kinchen, S., Shanklin, S., Ross, J., Hawkins, J., William, M.M., Lowry, R., McManus, T., Chyen, D., Lim, C., Whittle, L., Brener, N., \& Wechler, H. (2010). Youth risk behavior surveillanceUnited States, 2009. MMWR Surveill Summ, 59(5), 1-142.

Ellis, W. E., Chung-Hall, J. \& Dumas, T. M. (2013). The role of peer group aggression in predicting adolescent dating violence and relationship quality. Journal of Youth and Adolescence, 42, 487-499. doi: 10.1007/s10964-012-9797-0

Fernández-Fuertes, A. A. \& Fuertes, A. (2010). Physical and psychological aggression in dating relationships of Spanish adolescents: Motives and consequences. Child Abuse \& Neglect, 34, 183-191. doi:10.1016/j.chiabu.2010.01.002

Fernández-González, L., O’Leary, K. D. \& Muñoz-Rivas, M. J. (2014). Age-Related Changes in Dating Aggression in Spanish High School Students. Journal of Interpersonal Violence, 29, 1132-1152. doi:10.1177/0886260513506057

Ferrer Pérez, V. A. \& Bosch Fiol, E. (2005). Introduciendo la perspectiva de género en la investigación psicológica sobre violencia de género. Anales de Psicología, 21(1), 1-10.

Field, A.P. (2001). Meta-analysis of correlation coefficients: A Monte Carlo comparison of fixed- and random-effects methods. Psychological Methods, $6,161-180$
Foshee, V. A., Karriker-Jaffe, K. J., Reyes, H. L. M., Ennett, S. T., Suchindran, C., Bauman, K. E. \&y Benefield, T. S. (2008). What accounts for demographic differences in trajectories of adolescent dating violence? An examination of intrapersonal and contextual mediators. Journal of Adolescent Health, 42, 596-604. doi: 10.1016/j.jadohealth.2007.11.005

*Garthe, R. C., Sullivan, T. N. \& McDaniel, M. A. (2016). A meta-analytic review of peer risk factors and adolescent dating violence. Psychology of Violence, 7, 45-57. doi:10.1037/vio0000040

Gignac, G. E. \& Szodorai, E. T. (2016). Effect size guidelines for individual differences researchers. Personality and individual differences, 102, 74-78. https://doi.org/10.1016/j.paid.2016.06.069

Gressard, L. A., Swahn, M. H. \& Tharp, A. T. (2015). A First Look at Gender Inequality as a Societal Risk Factor for Dating Violence. American Journal of Preventive Medicine, 49, 448-457. https://doi.org/10.1016/j.amepre.2015.05.017

Hernández Oliver, B. \& Doménech del Río, I. (2017). Violencia de género y jóvenes: incomprensible pero real. METAMORFOSIS. Page 48-61. Retreived from http://revistametamorfosis.es/index.php/ metamorfosis/article/view/62

*Hérbert, M., Daspe, M. E., Lapierre, A., Godbout, N., Blais, M., Fernet, M. \& Lavoie, F. (2017). A Meta-Analysis of Risk and Protective Factors for Dating Violence Victimization: The Role of Family and Peer Interpersonal Context. Trauma, Violence and Abuse, 1-17. doi: $10.1177 / 1524838017725336$

Heise, L. (1998). Violence against women: an integrated ecological Framework. Violence Against Women. 4 (3), 262-290.

Hemphill, J.F. (2003). Interpreting the magnitude of correlation coefficients. American Psychologist, 58, 78-79. doi: 10.1037/0003066X.58.1.78

Hirigoyen, M.F (2005) Mujeres Maltratadas. Los Mecanismos de Violencia en la Pareja. Buenos Aires: Paidós Contextos.

Howard, D. E., Debnam, K. J. \& Wang, M. Q. (2013). Ten-year trends in physical dating violence victimization among US adolescent females. Journal of school health, 83(6), 389-399. doi: 10.1111/josh.12042

Instituto de la Juventud de España (INJUVE) (2016). Informe Juventud en España 2016. Retrieved from: http://www.injuve.es/sites/default / files/2017/24/publicaciones/informe-juventud-2016.pdf

Jennings, W. G., Okeem, C., Piquero, A. R., Sellers, C. S., Theobald, D. \& Farrington, D. P. (2017). Dating and intimate partner violence among young persons aged 15-30: Evidence from a systematic review. Aggression and violent behavior, 33, 107-125. doi: 10.1016/j.avb.2017.01.007

Johnson, B. T. \& Eagly, A. H. (2014). Meta-analysis of social-personality psychological research. In H. T. Reis \& C. M. Judd (Eds.), Handbook of research methods in social and personality psychology (2nd Ed., pp. 675-707) London: Cambridge University Press.

*Johnson, R. M., LaValley, M., Schneider, K. E., Musci, R. J., Pettoruto, K. \& Rothman, E. F. (2017). Marijuana use and physical dating violence among adolescents and emerging adults: A systematic review and metaanalysis. Drug \& Alcohol Dependence, 174, 47-57. doi 10.1016/j.drugalcdep.2017.01.012

Joly, L. E. \& Connolly, J. (2016). Dating violence among high-risk young women: a systematic review using quantitative and qualitative methods. Behavioral Sciences, 6(1), 7. doi:10.3390/bs6010007

Kliem, S., Baier, D. \& Bergmann, M. C. (2018). Prevalence of Teen Dating Violence in Romantic Relationships Among Teenagers: Results of a Representative Survey in Lower Saxony. KINDHEIT UND ENTWICKLUNG, 27, 110-125. doi: 10.1026/0942-5403/a000251

Lau, M., Nguyen, S. \& Markham, C. (2018). Sexual Dating Violence among Asian American Adolescents. Journal of Adolescent Health, 62, S60. https://doi.org/10.1016/j.jadohealth.2017.11.123

Lewis, S. F., \& Fremouw, W. (2001). Dating violence: A critical review of the literature. Clinical Psychology Review, 21, 105-127. doi: 10.1016/S02727358(99)00042-2

*Madigan, S., Wade, M., Tarabulsy, G., Jenkins, J. M. \& Shouldice, M. (2014). Association between abuse history and adolescent pregnancy: a meta-analysis. Journal of Adolescent Health, 55, 151-159. doi: 10.1016/j.jadohealth.2014.05.002

Miller-Johnson, S. \& Costanzo, P. (2004). If you can't beat 'em . . . induce 
them to join you: Peer-based interventions during adolescence. In J. B. Kupersmidt \& K. A. Dodge (Eds.), Children's peer relations: From development to intervention to policy: A festschrift in honor of John D. Coie (209-222). Washington, DC: American Psychological Association. doi: 10.1037/10653-01

Ministerio de Sanidad Servicios Sociales e Igualdad. (2015). Macroencuesta de violencia contra la mujer 2015. Avance de resultados. Retreived from http://www.violenciagenero.msssi.gob.es/violenciaEnCifras/macroen cuesta2015/pdf/AVANCE_MACROENCUESTA_VIOLENCIA_C ONTRA_LA_MUJER_2015.

Moral, M. D. L. V., García, A., Cuetos, G. \& Sirvent, C. (2017). Violencia en el noviazgo, dependencia emocional y autoestima en adolescentes y jóvenes españoles. Revista Iberoamericana de Psicología y Salud. 8, 96-107. doi:10.23923/j.rips.2017.08.009

*Moore, T. M., Stuart, G. L., Meehan, J. C., Rhatigan, D. L., Hellmuth, J. C. \& Keen, S. M. (2008). Drug abuse and aggression between intimate partners: A meta-analytic review. Clinical Psychology Review, 28, 247-274. doi: 10.1016/j.cpr.2007.05.003

Muñoz-Rivas, M. J., González-Lozano, P., Fernández-González, L., Fernández Ramos, S. \& García Sánchez, R. (2015). Violencia en el noviazgo : realidad y prevención. Madrid: Pirámide.

Niolon, P. H., Vivolo-Kantor, A. M., Latzman, N. E., Valle, L. A., Kuoh, H., Burton, T., Taylor, B. G., Tharp, A. T. (2015). Prevalence of teen dating violence and co-occurring risk factors among middle school youth in high-risk urban communities. Journal of Adolescent Health, 56, S5-S13. doi:10.1016/j.jadohealth.2014.07.019

Orpinas, P., Hsieh, H.-L., Song, X., Holland, K. \& Nahapetyan, L. (2013). Trajectories of Physical Dating Violence from Middle to High School: Association with Relationship Quality and Acceptability of Aggression. Journal of Youth and Adolescence, 42, 551-565. doi:10.1007/s10964-0129881-5

*Park, S. \& Kim, S. H. (2018). The power of family and community factors in predicting dating violence: A meta-analysis. Aggression and Violent Behavior, 40, 19-28. doi: 10.1016/j.avb.2018.03.002

Pazos, M., Oliva, A. \& Gómez, Á. H. (2014). Violence in young and adolescent relationships. Revista Latinoamericana de Psicología, 46(3), 148-159.

Public Health Agency of Canada (2012). Violence in dating relationships. Retreived from http://www.phac-aspc.gc.ca/sfvavf/sources/fem/fem-relations/index-eng.php.

Puente-Martínez, A., Ubillos-Landa, S., Echeburúa, E. y Páez-Rovira, D. (2016). Factores de riesgo asociados a la violencia sufrida por la mujer en la pareja: una revisión de meta-análisis y estudios recientes. Anales de psicología, 32, 295-306. Doi: bttp://dx.doi.org/10.6018/analesps.32.1.189161

Puente-Martínez, A. P. (2017). Breaking the silence! afrontamiento y regulación emocional en violencia de género/ (Doctoral dissertation, Universidad del País Vasco-Euskal Herriko Unibertsitatea).

Reidy, D. E., Ball, B., Houry, D., Holland, K. M., Valle, L. A., Kearns, M. C., Marshall, K.J. \& Rosenbluth, B. (2016). In search of teen dating violence typologies. Journal of Adolescent Health, 58, 202-207. doi: 10.1016/j.jadohealth.2015.09.028

Richard, F.D., Bond, C.F. \& Stokes-Zoota, J.J. (2003). One hundred years of social psychology quantitatively described. Review of General Psychology, 7(4), 331-363. doi: 10.1037/1089-2680.7.4.331

Rosenthal, R. (1984). Meta-analytic procedures for social research (2nd ed.). Newbury Park, CA: Sage

*Rothman, E. F., McNaughton Reyes, L., Johnson, R. M. \& LaValley, M. (2012). Does the alcohol make them do it? Dating violence perpetration and drinking among youth. Epidemiologic reviews, 34, 103-119. doi: $10.1093 /$ epirev/mxr027

Rubio-Garay, F., Carrasco, M. Á., Amor, P. J. \& López-González, M. A. (2015). Factores asociados a la violencia en el noviazgo entre adolescentes: una revisión crítica. Anuario de Psicología Jurídica, 25, 47-56. doi: https://doi.org/10.1016/j.apj.2015.01.001

Sebastián, J., Verdugo, A. \& Ortiz, B. (2014). Jealousy and violence in dating relationships: gender-related differences among a Spanish sample. The Spanish Journal of Psychology, 17, E94. 1-12. doi: https://doi.org/10.1017/sjp.2014.99

Shorey, R. C., Cornelius, T. L. \& Bell, K. M. (2008). A critical review of theoretical frameworks for dating violence: Comparing the dating and marital fields. Aggression and Violent Behavior, 13, 185-194. https://doi.org/10.1016/j.avb.2008.03.003.

Silverman, J. G., Raj, A., Mucci, L. A. \& Hathaway, J. E. (2001). Dating violence against adolescent girls and associated substance use, unhealthy weight control, sexual risk behavior, pregnancy, and suicidality. Jama, 286, 572-579. doi:10.1001/jama.286.5.572

Singh, V., Walton, M. A., Whiteside, L. K., Stoddard, S., Epstein-Ngo, Q., Chermack, S. T. \& Cunningham, R. M. (2014). Dating Violence Among Male and Female Youth Seeking Emergency Department Care. Annals of Emergency Medicine, 64, 405-412.e1. doi: 10.1016/j.annemergmed.2014.05.027

Smith, P. H., White, J. W. \& Holland, L. J. (2003). A longitudinal perspective on dating violence among adolescent and college-age women. American Journal of Public Health, 93(7), 1104-1109.

Steinberg, L. (2014). Adolescence (10th ed.). New York, NY: McGraw- Hill Higher Education.

Stith, S. M., Smith, D. B., Penn, C. E., Ward, D. B. \& Tritt, D. (2004). Intimate partner physical abuse perpetration and victimization risk factors: A meta-analytic review. Aggression and violent behavior, 10, 65-98. doi:10.1016/j.avb.2003.09.001

*Sugarman, D. B. \& Hotaling, G. T. (1997). Intimate violence and social desirability a meta-analytic review. Journal of Interpersonal Violence, 12, 275-290. doi: 10.1177/088626097012002008

Teitelman, A. M., Ratcliffe, S. J., McDonald, C. C., Brawner, B. M. \& Sullivan, C. M. (2011). Relationships between physical and non-physical forms of intimate partner violence and depression among urban minority adolescent females. Child and adolescent mental health, 16(2), 92100

Urrútia, G. \& Bonfill, X. (2010). Declaración PRISMA: una propuesta para mejorar la publicación de revisiones sistemáticas y metaanálisis. Medicina clínica, 135, 507-511. doi:10.1016/j.medcli.2010.01.015

Vagi, K. J., Rothman, E. F., Latzman, N. E., Tharp, A. T., Hall, D. M. \& Breiding, M. J. (2013). Beyond correlates: a review of risk and protective factors for adolescent dating violence perpetration. Journal of Youth and Adolescence, 42, 633-49. doi:10.1007/s10964-013-9907-7

Vezina, J. \& Hebert, M. (2007). Risk factors for victimization in romantic relationships of young women: A review of empirical studies and implications for prevention. Trauma, Violence, \& Abuse, 8(1), 33-66.

Viejo, C. (2014). Physical dating violence: towards a comprehensible view of the phenomenon/Violencia física en las relaciones sentimentales adolescentes: hacia la comprensión del fenómeno. Infancia y Aprendiraje, 37, 785-815. doi: 10.1080/02103702.2014.977110

Viejo, C., Monks, C. P., Sánchez, V. \& Ortega-Ruiz, R. (2016). Physical Dating Violence in Spain and the United Kingdom and the Importance of Relationship Quality. Journal of Interpersonal Violence, 31, 1453-1475. doi:10.1177/0886260514567963

Walker, L. E. (1989). Psychology and Violence Against Women. American Psychologist, 44(4), 695-702

Wilson, D.B. (2016). Practical Meta-Analysis Effect Size Calculator. Retrieved from:

http://www.campbellcollaboration.org/escalc/html/EffectSizeCalcula tor-SMD-main.php

Williams, S. L. \& Frieze, I. H. (2005). Patterns of violent relationships, psychological distress, and marital satisfaction in a national sample of men and women. Sex Roles, 52, 11-12, doi: 771-784. 10.1007/s11199-0054198-4

*Wincentak, K., Connolly, J. \& Card, N. (2016). Teen Dating Violence: A Meta-Analytic Review of Prevalence Rates. Psychology of Violence. 7, 224241. doi: $10.1037 / \mathrm{a} 0040194$

Ybarra, M. L., Espelage, D. L., Langhinrichsen-Rohling, J., \& Korchmaros, J. D. (2016). Lifetime Prevalence Rates and Overlap of Physical, Psychological, and Sexual Dating Abuse Perpetration and Victimization in a National Sample of Youth. Archives of Sexual Behavior, 45, 10831099. doi:10.1007/s10508-016-0748-9

Zaha, R., Helm, S., Baker, C. \& Hayes, D. (2013). Intimate partner violence and substance use among Hawai $i$ youth: An analysis of recent data from the Hawai 'i Youth Risk Behavior Survey. Substance Use \& Misuse, 48, 11-20. doi:10.3109/10826084.2012.720334 